\title{
SAĞLIKTA DÖNÜŞÜM PROGRAMI SONRASI SAĞLIK HİZMETİ MEMNUNİYETİ: İSTANBUL ÖRNEĞİ*
}

\author{
HEALTH SERVICES SATISFACTION SURVEY AFTER THE \\ HEALTH TRANSFORMATION PROGRAMME: ISTANBUL CASE
}

\author{
Gülay AKGÜL YILMAZ ${ }^{* *}$ \\ Müge YETKİN ATAER ${ }^{* * *}$ \\ Gözde NALBANT EFE ${ }^{* * * *}$
}

\section{Özet}

Türkiye’de daha etkin sağlık hizmeti sunumu hedefine yönelik olarak 2003 yılı itibarılla Sağlıkta Dönüşüm Programı uygulamaya geçirilmiştir. Bu uygulama ile sağlık hizmetinin sunumunda ve finansmanında reform gerçekleștirilmiştir. Söz konusu reformlar ile bir taraftan halkın sağlık hizmetine erişimini kolaylaştırmak diğer taraftan da maliyet etkinliği sağlanmaya çalışılmıştır. Bu bağlamda bir dizi tedbir uygulamaya konulmuştur. Hizmet sunumu alanındaki reformun en önemli yapı taşları; ilk adım sağlık hizmetinin kırsalda sağlık evi ve ocakları, kentlerde aile hekimleri tarafından vatandaş odaklı olarak sunumuna geçiş, hastanelerde randevu sistemine geçiş ve özel hastanelerden faydalanabilme imkanlarının genişletilmesi olmuştur. Hizmetin finansmanında reformun temel taşlarını ise; sağlık sigorta sisteminin tek çatı altında toplanması, 2006 yılından itibaren performans sisteminin uygulamaya geçirilmesi ve ilaç sektörünü düzenleyici tedbirler oluşturmuştur. Ölçülebilir performans uygulamaları ile aynı miktar faktör ile (sağlık çalışanı) bir taraftan mümkün olduğunca daha fazla kişiye hizmet üretimi, diğer taraftan bunun ücrete yansıması hedeflenmiştir. İlaç sektörünü düzenleyici uygulamalar ile tedavi edici sağlık hizmetleri maliyetini azaltmak, genel sağlık sigortasına geçiş ile sağlık hizmetini üretmeye yönelik daha etkin bir kaynak yönetimi sağlanmaya çalışılmıştır. Bahsedilen uygulamalar hizmeti talep eden hastalar üzerinde etkili olmuştur. Çalışmamızda, İstanbul'da yaşayan bireylerin sağlık hizmeti memnuniyeti ölçülmeye çalışllmıştır.

Anahtar Kelimeler: Sağlık hizmetleri, sağlık ekonomisi, sağlık politikası, sağlıkta dönüşüm programı

JEL Sınıflandırması: H51, I11, I13, I18

* Bu çalışma, Marmara Üniversitesi Bilimsel Araştırma Projeleri Birimi (BAPKO) tarafından desteklenmiş bir projenin ürünüdür.

** Prof. Dr., Marmara Üniversitesi İktisat Fakültesi Maliye Bölümü, gulayyilmaz@marmara.edu.tr , Orcid İd: 0000-0003-0677-7841

*** Arş. Gör., İstanbul Medeniyet Üniversitesi Siyasal Bilgiler Fakültesi Maliye Bölümü, muge.yetkin@medeniyet.edu.tr, Orcid İd: 0000-0002-9730-6529

**** Arş. Gör., İstanbul Medeniyet Üniversitesi Siyasal Bilgiler Fakültesi Maliye Bölümü, gozde.nalbant@medeniyet.edu. tr , Orcid İd: 0000-0002-4651-2007 


\begin{abstract}
Health Transformation Programme was started to apply since 2003, directed to reach the aim of more efficient health service in Turkey. With this programme, a reform was tried to be realized at the health service supply at the same time with a reform at the finance of health services. With the reforms that mentioned above, the cost efficiency was tried to be ensured as well as making easy the access to the health services. In that context, a series of measures applied. The most important milestones of the reform at the service supply area as follows; the transition of the health services to the citizen focused supply by the health houses and community health centers at the rural areas, and by the primary health services at the urban areas. The transition to the appointment system at hospitals and the extend of opportunities on the utilization from the private hospitals. The main pillars of the reform at the finance of the services are as follows; convergence of the health insurance system, applying the performance measurement system since 2006 and the regulative measures for the pharmaceutical industry. With the measurable performance applications, the service production for the most possible quantity of people with the same quantity of factors (health sector employees); at the same time, reflections of that on the prices were aimed. With the regulative applications at the pharmaceutical sector, lowering the cost of health services was aimed, with the transition to the general health insurance system, more efficient source management that is directed produce health service production was tried to be ensured. The applications that mentioned above have been influential on the patients who demand the health services. In our research project, we tried to measure the satisfaction level of patients who live in Istanbul, regarding the health service.
\end{abstract}

Keywords: Health services, health economics, health policy, health transformation programme

JEL Classification: H51, I11, I13, I18

\title{
I. Giriş
}

Sağlık, bireyin sadece hastalığının ya da sakatlığının olmaması değildir. Sağlıklı birey, fiziksel, zihinsel ve sosyal bakımdan iyi durumda olan bireydir ${ }^{1}$. Sağlık hizmetleri, faydadan dışlanabilirlik $^{2}$ ve tüketiminde rekabet özelliğine sahip ${ }^{3}$ hizmetler olup aynı zamanda yüksek pozitif dışsallık yayan hizmetlerdir. Sağlık hizmetleri, koruyucu ve tedavi edici sağlık hizmetlerinden oluşmaktadır. Tedavi edici sağlık hizmetlerinin, bu hizmetlerden doğrudan faydalanan bireylere sağladığ 1 faydaların yanı sıra hastalığın bulaşıcılığını azalttığı ya da tamamen yok ettiği için toplumsal faydası da söz konusudur. Koruyucu sağlık hizmetlerinden ise bir bütün olarak doğrudan toplum yararlanmaktadır ${ }^{4}$. Kamu kesiminin bu alana müdahale gerekçesi sadece sağlık hizmetinin yaydığı pozitif dışsallık değildir. Diğer müdahale gerekçeleri; hizmet sunucuları arasında özel piyasada oluşacak sınırlı rekabet ${ }^{5}$, tüketiciler arasındaki eksik bilgi sahibi

1 World Health Organization. (1946). Constitution of the World Health Organization. http://apps.who.int/gb/bd/ PDF/bd47/EN/constitution-en.pdf?ua=1 (Erişim Tarihi: 25.10.2018)

2 Samuelson, P. A. (1954). The Pure Theory of Public Expenditures. The Review of Economics and Statistics, 36(4): 387.

3 Samuelson, 1954, 387

4 Bulutoğlu, K. (2003). Kamu Ekonomisine Giriş: Demokraside Devletin Ekonomik Bir Kuramı, İstanbul, Yapı Kredi Yayınları, s. 263.

5 Stiglitz, J. E. (2000). Economics of the Public Sector, NewYork/London, W. W. Norton \& Company, s. 309. 
olma durumu ${ }^{6}$ ve gelir eşitsizliği nedeniyle sağlık hizmetine ulaşamayacak durumda olanların güvence altına alınmasıdır ${ }^{7}$. Sağlık hizmetleri hızlı bir şekilde tüketilen ve etkisini zaman içinde gösteren hizmetlerdir. Hizmet verimli bir şekilde üretilmeli, adil ve yeterli düzeyde dağıtılmalı ve toplumdaki tüm bireyler hiçbir ayrım yapılmaksızın bu hizmetten yararlanabilmelidir. Sağlık hizmetinin olmaması kabul edilebilir bir durum değildir. Bu nedenle sağlık öncelikle kamusal bir mal ve hizmet olarak görülmeli ayrıca özel kesim tarafından da üretilebilmelidir. ${ }^{8}$

Türkiye'de 1961 Anayasası'nda daha sonra 1982 Anayasası'nda Türkiye Cumhuriyeti devletinin niteliği sosyal devlet olarak belirtilmiştir ${ }^{9}$. Sosyal devlet anlayışının hakim olduğu bir ülkede sağlık hizmetinin esas itibarıla kamu kesimi tarafından yerine getirilmesi gerekmektedir ${ }^{10}$. Türkiye'de sağlık hakkı anayasal düzeyde ilk kez 1961 Anayasası́nda kendisine yer bulmuştur. Halen yürürlükte bulunan 1982 Anayasası'nın 56. Maddesi; “Herkes sağlıklı ve dengeli bir çevrede yaşama hakkına sahiptir. Çevreyi geliştirmek, çevre sağlığını korumak ve çevre kirlenmesini önlemek Devletin ve vatandaşların ödevidir. Devlet herkesin hayatını beden ve ruh sağlı̆̆ içinde sürdürmesini sağlama; insan ve madde gücünde tasarruf ve verimi artırarak, işbirliğini gerçekleştirmek amacıyla sağlık kuruluşlarını tek elden planlayıp hizmet vermesini düzenler. Devlet, bu görevini kamu ve özel kesimdeki sağlık ve sosyal kurumlardan yararlanarak, onları denetleyerek yerine getirir. Sağlık hizmetlerinin yaygın bir şekilde yerine getirilmesi için kanunla genel sağlık sigortası kurulabilir.” şeklindedir. Söz konusu madde hükmünden de anlaşıldığı üzere, devlet herkesin beden ve ruh sağlı̆̆ içinde yaşamını sürdürmesini sağlamak, etkinlik ve verimlilik ilkeleri gereği sağlık hizmetini tek elden planlayıp, denetimlerini yaparak sağlık hizmeti sunumunun gerçekleşmesini temin etmek zorundadır.

Türkiye'de sağlık hizmetlerinin, nitelik ve nicelik bakımından diğer OECD ülkeleriyle karşılaştırıldığında yeterli olmadığı, sağlık hizmetine erişimdeki adaletsizliklerin varlığı ve sağlık hizmetinin finansman ve sunumunda mali sürdürülebilirliğin olmadığından söz edilebilir ${ }^{1112}$. Türkiye’nin sağlık hizmetine ilişkin sorunları başta ekonomik olmak üzere, eğitsel, demografik ve organizasyonda yetersizlik gibi çok sayıda nedene bağlanmaktadır ${ }^{13}$.

Sağlık sektöründe karşılaşılan bu sorunları dikkate alarak 2003 yılı itibarıyla Sağlıkta Dönüşüm Programı uygulamaya geçirilmiştir. Sağlıkta Dönüşüm Programı’nın amaçları; sağlık hizmetlerinin etkili, verimli ve hakkaniyete uygun bir şekilde organize edilmesi, finansmanının sağlanması ve

Stiglitz, 2000, 309.

Stiglitz, 2000, 7 ve 309.

Ayyıldız Onaran, Z. (2014). Sağlığın Mikrosu, İstanbul, Derin Yayınları, s. 22 ve s. 114.

Akgül Yılmaz, G. (2006). OECD Ülkeleri ve Türkiye'de Sosyal Devlet ve Sosyal Harcamalar, İstanbul, Arıkan Basım, s. 1 .

10 Akgül Yılmaz, 2006, 10.

11 OECD. (2008). OECD Sağllk Sistemi İncelemeleri Türkiye, https://sbu.saglik.gov.tr/ekutuphane/kitaplar/oecdkitap. pdf (Erişim Tarihi: 20.10.2018), s. 36.

12 T.C. Sağlık Bakanlığı (2003). Sağlıkta Dönüşüm, https://www.saglik.gov.tr/TR,11415/saglikta-donusum-programi. html (Erişim Tarihi: 20.10.2018), s. 11-21.

13 Şener, O. (2006). Kamu Ekonomisi, İstanbul, Beta, s. 388. 
sunulmasıdır. Temel ilkeleri; insan merkezlilik, sürdürülebilirlik, sürekli kalite gelişimi, katılımcılık, uzlaşmacılık, gönüllülük, güçler ayrılığı, desantralizasyon ve hizmette rekabettir ${ }^{14}$.

Sağlıkta Dönüşüm Programı ile sağlık hizmeti sunumunda ve finansmanında reform gerçekleştirilmiştir. Söz konusu reformlar ile halkın sağlık hizmetine erişimini kolaylaştırmak ve maliyet etkinliği hedeflenmiştir. Bu bağlamda, hizmet sunumu alanındaki reformun en önemli yapı taşlarını; ilk adım sağlık hizmetinin kırsalda sağlık evi ve ocakları, kentlerde aile hekimleri tarafından vatandaş odaklı olarak sunumuna geçiş, hastanelerde randevu sistemine geçiş ve özel hastanelerden faydalanabilme imkanlarının genişletilmesi oluşturmuştur. Hizmetin finansmanı alanındaki reformun temel taşlarını ise; sağlık sigorta sisteminin tek çatı altında toplanması, 2006 yılından itibaren performans sisteminin uygulamaya geçirilmesi ve ilaç sektörünü düzenleyici tedbirler oluşturmuştur. Ölçülebilir performans uygulamaları ile aynı miktar sağlık çalışanı ile bir taraftan mümkün olduğunca daha fazla kişiye hizmet üretimi sağlanmaya çalışılmış. Söz konusu mekanizmanın işleyişi performansa dayalı ücret uygulaması ile desteklenmiştir. İlaç sektörünü düzenleyici uygulamalar ile tedavi edici sağlık hizmetleri maliyetini azaltmak, genel sağlık sigortasına geçiş ile sağlık hizmetini üretmeye yönelik daha etkin bir kaynak yönetimi oluşturulmaya çalışılmıştır. Bahsedilen uygulamalar hizmetten faydalanan başka bir deyişle sağlık hizmeti talep eden hastalar üzerinde etkili olmuştur.

Bugüne kadar sağlık hizmetlerinden memnuniyeti ölçmeye yönelik çalışmaların farklı noktalara odaklanmış oldukları görülmektedir. Tip fakülteleri mensupları tarafından, genellikle mensubu bulundukları fakülte hastanelerinde ya da farklı hastanelerde hasta memnuniyeti ölçümüne yönelik çalışmalar ortaya koyulmuştur ${ }^{151617}$. İktisadi ve idari bilimler fakültelerinde ise hem fakülte öğretim üyeleri tarafından yapılan akademik çalışmalar hem de lisansüstü öğrencilerin hazırladığı tez çalışmaları mevcuttur ${ }^{181920}$. Bu çalışmaların bazılarında basit istatistiki tablolar kullanılıp yorumlanırken, bir kısmında da ileri istatistiksel analizler yer almaktadır. Sağlık hizmetinden memnuniyeti ölçmeye yönelik akademik çalışmalar büyük ölçüde il örnekleri ya da mikro mekanlar ile sınırlıdır. Türkiye İstatistik Kurumu da genel sağlık hizmetinden memnuniyet düzeyi verisi yayınlamaktadır ${ }^{21}$.

14 T.C. Sağlık Bakanlığ

15 Erdem, R. ve diğerleri (2008). Hasta Memnuniyetinin Hasta Bağlllı̆̆ı Üzerine Etkisi, Erciyes Üniversitesi İİBF Dergisi, 32: 95-110.

16 Emhan, A., Bez, Y. (2010). Bir Üniversite Hastanesine Başvuran Hastaların Memnuniyet Düzeyleri, Dicle Tıp Dergisi, 37(3): 241-247.

17 Sarp, N., Tükel, B. (1999). İbn-i Sina Hastanesinde Hasta Memnuniyeti Araştırması, Ankara Üniversitesi Tıp Fakültesi Mecmuas1, 52: 147-151.

18 Koçak, O., Tiryaki, D. (2011). Sosyal Devlet Anlayışında Sağlık Politikalarının Önemi ve Sağllkta Dönüşüm Programının Değerlendirilmesi: Yalova Örneği, İstanbul Ticaret Üniversitesi Sosyal Bilimler Dergisi, 10(19): 55-88.

19 Çelikay, F., Gümüş, E. (2011). Sağlıkta Dönüşümün Ampirik Analizi, Ankara Üniversitesi SBF Dergisi, 66(3): 55-92.

20 Soysal, A., Yağar, F. (2015). Sağlıkta Dönüşüm Programı: Kahramanmaraş Sütçü İmam Üniversitesi Araştırma ve Uygulama Hastanesinde Bir Araştırma, KSÜ Sosyal Bilimler Dergisi,12(2): 313-344.

21 Türkiye İstatistik Kurumu (TÜİK). Yaşam Memnuniyeti Araştırması, 2017, http://www.tuik.gov.tr/ PreHaberBultenleri.do?id=27590 (Erişim Tarihi: 25.10.2018). 
Çalışmamızda, İstanbul'da yaşayan bireylerin sağlık hizmeti memnuniyeti ölçülmeye çalışılmıştır. Söz konusu memnuniyet ölçülürken, Sağlıkta Dönüşüm Programı’nın getirdiği yenilikler ve bu yeniliklerin memnuniyet üzerindeki etkileri bakımından derinleşme sağlanması ön planda tutulmuştur. Çalışmanın ikinci bölümünde, araştırmanın kapsamı, yöntemi ve verilerin toplanması açıklanmıştır. Bulgular bölümünde ise öncelikle güvenirlik analiz değeri sunulmuştur. Araştırmaya katılan bireylerin cinsiyet, medeni durum, mesleki durum, yaş, hane halkı toplam geliri, eğitim seviyesi, bakmakla yükümlü olunan kişi sayısı gibi demografik özelliklerini içeren bilgilere, daha sonra bireylerin sağlık hizmetinden memnuniyetine yönelik analize yer verilmiştir. Söz konusu analiz memnuniyeti etkileyen faktörlerin çeşitli bağımsız değişkenler göz önünde bulundurularak kendi aralarında istatistiksel açıdan anlamlı bir fark olup olmadığı bakımından yapılmıştır. Bağımsız gruplar t testi ve tek yönlü ANOVA analizi uygulanmıştır. Son bölümde analizin sonuçlarına yer verilmiştir.

\section{Araştırmanın Kapsamı, Yöntemi ve Verilerin Toplanması}

İstanbul'da ikamet eden bireylerin sağlık hizmetinden memnuniyetinin araştırıldığı bu çalışmada, ana kütle olarak İstanbul ili alınmıştır. Türkiye İstatistik Kurumu Adrese Dayalı Nüfus Kayıt Sistemi verilerine göre 2017 yılında İstanbul'da ikamet eden bireylerin sayısı 15.029.231 kişidir. ${ }^{22}$ Yapılan çalışmada örneklem belirlenirken İstanbul'da hem Anadolu hem de Avrupa yakasında ikamet eden 18 yaş üstü bireylere ulaşılmıştır.

Çalışmada kullanılan veriler 15 Şubat-15 Nisan 2018 tarihleri arasındaki dönemde basit tesadüfî örnekleme yöntemiyle yüz yüze gerçekleştirilen ve internet üzerinden gönderilen anket sorularına alınan cevaplardan toplanmıștır.

Anket formu içeriği, ilgili literatürden, Sağlık Bakanlığı’nın hazırlamış olduğu ilerleme ve değerlendirme raporlarından ${ }^{232425}$ ve ilgili kanun ${ }^{262728}$, tebliğ ${ }^{29}$ ve yönetmeliklerden ${ }^{30}$ edinilen bilgilere dayalı olarak oluşturulmuştur. Araştırmada kullanılan anket formunun son haline, ilk hazırlanan anket formunun 40 kişiyle yapılan test anketleri sonrasında gerekli görülen değişikliklerin yapılmasıyla ulaşılmıştır. Başlangıçtaki anket formu 28 soru/ifade olarak

22 Türkiye İstatistik Kurumu (TÜİK). Adrese Dayalı Nüfus Kayıt Sistemi, Yıllara Göre İl Nüfusları, 2017, http://www. tuik.gov.tr/PreTablo.do?alt_id=1059 (Erişim Tarihi: 20 Nisan 2018).

23 T.C. Sağlık Bakanlığı, 2003, s. 26-37.

24 Akdağ, R. (2008). İlerleme Raporu Türkiye Sağlıkta Dönüşüm Programı. T.C. Sağlık Bakanlığı, Yayın No: 349, s. 33-109.

25 Akdağ, R. (2012). Sağlıkta Dönüşüm Programı Değerlendirme Raporu (2003-2011). T. C. Sağlık Bakanlığı, https:// dosyasb.saglik.gov.tr/Eklenti/5131,sdpturkpdf.pdf?0 (Erişim Tarihi: 25.10.2018), s. 51-239.

265502 Nolu Sosyal Güvenlik Kurumu Kanunu (20.05.2006 tarih, 26173 sayılı T.C. Resmi Gazete).

275510 Nolu Sosyal Sigortalar ve Genel Sağlık Sigortası Kanunu (16.06.2006 tarih, 26200 sayılı T.C. Resmi Gazete).

285947 Nolu Üniversite ve Sağlık Personelinin Tam Gün Çalışmasına Dair Kanun (30.01.2010 tarih, 27478 sayılı T.C. Resmi Gazete).

29 Sağlık Uygulama Tebliği (24.03.2013 tarih, 28597 sayılı T.C. Resmi Gazete).

30 Aile Hekimliği Uygulama Yönetmeliği (25.01.2013 tarih, 28539 sayılı T.C. Resmi Gazete). 
tasarlanmışken, test anketleri sonrasında yapılan düzeltmeler ile 25'e indirilmiştir. Cevaplanmış anket formları incelendiğinde 720 anket içerisinde 164 anketin hatalı, eksik ve/veya tutarsız olduğuna karar verilerek bu anketler çalışma dışında tutulmuş ve analizler 556 anket formundan elde edilen bilgilere dayalı olarak gerçekleştirilmiştir.

Anket formu ${ }^{31}$, iki ana bölümden oluşmaktadır. İlk bölümünde, sağlıkta dönüşüm programı sonrasında bireylerin sağlık hizmetinden memnuniyetini ölçmek için devlet hastanelerindeki hizmet kalitesi, merkezi randevu sistemi, hekimlere getirilen performansa dayalı ücretlendirme ve tam gün yasası, sağlık hizmetinin finansmanını iyileştirmek üzere tüm sosyal güvenlik kurumlarının tek çatı altında toplanması ve katılım payı uygulaması, özel hastanelerden faydalanma imkanlarının artırılması ve aile hekimliklerinin hizmet sunumuna katkısı gibi faktörler göz önünde bulundurularak Sağlıkta Dönüşüm Programı ile hizmet sunumu ve finansmanı açısından getirilmiş düzenlemelerin, hizmeti talep eden hastalar nezdinde nasıl değerlendirildiğini ölçmeyi amaçlayan beşli likert tipi 25 adet soruya yer verilmiştir. İkinci bölümde ise ankete katılan bireylerin demografik özelliklerini ortaya koyan 10 adet soruya yer verilmiştir.

Çalışmanın kapsamını sınırlandırmak bakımından bu makalede, sağlık hizmetinden memnuniyeti oluşturan faktörlerden; sağlık hizmetine duyulan genel memnuniyet, katılım payı uygulamasına duyulan memnuniyet ve sağlik hizmetinde randevu sistemi ve muayene sürelerine ilişkin memnuniyet analiz edilmiştir. Sağlık hizmetine duyulan genel memnuniyeti ölçmeye ilişkin EK’te yer alan anket formundaki 2, 4, 10, 15, 18 ve 25 numaralı sorular; katılım payı uygulamasına duyulan memnuniyeti ölçmeye ilişkin 5, 11, 14, 16 ve 19 numaralı sorular; sağlık hizmetinde randevu sistemi ve muayene sürelerine yönelik memnuniyeti ölçmeye ilişkin ise 1,7, 8, 9 ve 13 numaralı sorular analiz kapsamına alınmıștır. Bahsedilen memnuniyet faktörlerine yönelik soruların çeşitli bağımsız değişkenler göz önünde bulundurularak kendi aralarında istatistiksel açıdan anlamlı bir fark olup olmadığı incelenmiştir. Bağımsız gruplar t testi ve Tek yönlü ANOVA analizi uygulanmıștır. Anketler, SPSS 22 programından yararlanılarak analiz edilmiştir.

\section{Bulgular}

\section{I. Güvenilirlik Analizi}

Çalışmada, araştırma sonuçlarının güvenilirliğini sınamak için güvenilirlik analizi yapılmıştır. $\mathrm{Bu}$ amaçla, Cronbach’’n Alpha güvenilirlik analizi kullanılmıştır. Cronbach’ın Alpha güvenilirlik analizi sonucu elde edilen test istatistiğinin 0.70’in üzerinde olması, çalışmanın bulgularına güvenilirliğin yüksek olduğunu gösterir.

İncelenen 25 likert sorularının güvenilirlik analizi sonucu, Cronbach's Alpha Değeri 0.87 olarak bulunmuştur. Bu sonuç, çalışmanın güvenilirliğinin yüksek olduğunu göstermektedir.

31 Anket formunda yer alan sorular çalışmanın ekinde yer almaktadır. 


\subsection{Araştırmaya Katılanların Demografik Özellikleri}

Bu bölümde araştırmaya katılan bireylerin cinsiyet, medeni durum, mesleki durum, yaş, hane halkı toplam geliri, eğitim seviyesi, bakmakla yükümlü olunan kişi sayısı gibi demografik özelliklerini içeren bilgilere yer verilmiştir. Bunun yanında bireylere araştırmanın kapsamı ile ilişkili olarak yöneltilen eski sistemde tabi oldukları sigorta kurumu, bir sağlık sorunu oluştuğunda gitmeyi ilk düşündükleri sağlık kurumu ve son bir yıl içinde kendileri ya da bir yakınları sebebiyle sağlık kurumlarına gitme sıklıklarına yönelik sorulara verilen cevapların dağılımına yer verilmiştir.

Tablo I: Ankete Katılan Bireylerin Demografik Özellikleri

\begin{tabular}{|c|c|c|c|}
\hline \multicolumn{4}{|c|}{ Ankete Katılan Birey Sayısı: 556} \\
\hline \multicolumn{2}{|c|}{ Bireylerin Yaş Dağılımı } & \multicolumn{2}{|c|}{ Bireylerin Cinsiyeti } \\
\hline $18-25$ yaş arası & $130(\% 23,4)$ & Kadın & $336(\% 60,4)$ \\
\hline $26-35$ yaş arası & $197(\% 35,6)$ & Erkek & $220(\% 39,6)$ \\
\hline $36-45$ yaş arası & $132(\% 23,7)$ & \multicolumn{2}{|c|}{ Bireylerin Mesleki Durumu } \\
\hline $46-55$ yaş arası & $61(\% 11)$ & Öğrenci & $87(\% 15,6)$ \\
\hline $56-65$ yaş arası & $30(\% 5,4)$ & Ev Kadını & $33(\% 5,9)$ \\
\hline 65 yaş üstü & $6(\% 1,2)$ & Emekli & $16(\% 2,9)$ \\
\hline \multicolumn{2}{|c|}{ Bireylerin Medeni Durumu } & Memur & $201(\% 36,2)$ \\
\hline Evli & $277(\% 49,8)$ & İşçi & $172(\% 30,9)$ \\
\hline Bekar & $251(\% 45,1)$ & İşveren & $9(\% 1,6)$ \\
\hline Boşanmış & $22(\% 4)$ & Kendi Hesabına Çalışan & $26(\% 4,7)$ \\
\hline Dul & $6(\% 1,1)$ & İşsiz & $6(\% 1,1)$ \\
\hline \multicolumn{2}{|c|}{ Bireylerin Eğitim Seviyesi } & Çalışmıyor & $6(\% 1,1)$ \\
\hline \multirow{3}{*}{$\begin{array}{l}\text { Okuryazar değil } \\
\text { İlkokulu bitirmemiş } \\
\text { İlkokul }\end{array}$} & $1(\% 0,2)$ & \multicolumn{2}{|c|}{ Hane Halkı Toplam Geliri } \\
\hline & $8(\% 1,4)$ & $1.600 \mathrm{TL}$ ve altında & $46(\% 8,3)$ \\
\hline & $21(\% 3,8)$ & $1.600 \mathrm{TL}-3.500 \mathrm{TL}$ & $196(\% 35,3)$ \\
\hline Ortaokul & $14(\% 2,5)$ & $3.501 \mathrm{TL}-5.000 \mathrm{TL}$ & $137(\% 24,6)$ \\
\hline Lise & $124(\% 22,3)$ & $5.001 \mathrm{TL}-7.000 \mathrm{TL}$ & $77(\% 13,8)$ \\
\hline Yüksekokul & $81(\% 14,6)$ & $7.001 \mathrm{TL}-10.000 \mathrm{TL}$ & $61(\% 11)$ \\
\hline Lisans & $190(\% 34,2)$ & 10.000 TL üstü & $39(\% 7)$ \\
\hline Yüksek Lisans & $80(\% 14,4)$ & \multicolumn{2}{|c|}{ Eski Sistemde Tabi Olunan Sigorta Kurumu } \\
\hline Doktora & $37(\% 6,7)$ & Yok & $27(\% 4,9)$ \\
\hline \multicolumn{2}{|c|}{ Bakmakla Yükümlü Olunan Kişi Sayısı } & SSK & $321(\% 57,7)$ \\
\hline Yok & $298(\% 53,6)$ & BAĞ-KUR & $40(\% 7,2)$ \\
\hline $1-2$ & $168(\% 30,2)$ & Emekli Sandığg & $139(\% 25)$ \\
\hline $3-4$ & $77(\% 13,8)$ & Özel Sigorta & $23(\% 4,1)$ \\
\hline 4'ten fazla & $13(\% 2,3)$ & Yeşil Kart & $6(\% 1,1)$ \\
\hline \multicolumn{2}{|c|}{$\begin{array}{l}\text { Sağlık Sorunu Olduğunda İlk Gitmeyi Düşündüğü } \\
\text { Sağlık Kurumu }\end{array}$} & \multicolumn{2}{|c|}{$\begin{array}{c}\text { Son Bir Yılda Kendisi ya da bir Yakını Sebebiyle Sağlık } \\
\text { Kurumlarına Gitme Sıklığı }\end{array}$} \\
\hline Aile Hekimi-Sağlık Ocağ & $81(\% 14,6)$ & Hiç gitmedim & $18(\% 3,2)$ \\
\hline Devlet Hastanesi & $234(\% 42,1)$ & En fazla 5 kere & $273(\% 49,1)$ \\
\hline Üniversite Hastanesi & $72(\% 12,9)$ & $6-10 \mathrm{kez}$ & $137(\% 24,6)$ \\
\hline Özel Hastane & $164(\% 29,5)$ & & \\
\hline Özel Muayenehane & $5(\% 0,9)$ & 10'dan fazla & 128 (\% 23) \\
\hline
\end{tabular}


Ankete katılan bireylerin demografik özelliklerinin frekans dağılımları ve genel toplam içerisindeki yüzdeleri Tablo 1'de yer almaktadır. Buradan hareketle ankete yoğunluklu olarak 18 ile 45 yaş aralığındaki bireylerin katıldığı görülmektedir. En yüksek katılımı ise \%35,6 oranı ile 26-35 yaş aralığındaki bireyler sağlamıştır. Bireylerin cinsiyet itibarıyla dağılımı incelendiğinde, $\% 60,4$ oranıyla kadınlar erkeklerden daha yüksek oranda katılım göstermiştir. Bireylerin medeni durumu itibarıyla dağılımı incelendiğinde, evli ve evli olmayan katılımcıların örneklem içerisinde neredeyse aynı oranda yer aldıkları görülmektedir. Ankete katılan bireylerin yaklaşık üçte ikisi memur ya da işçi olarak çalışmaktadır. Bunu \%15,6 katılım oranıyla öğrenciler izlemektedir. Ev kadını, emekli, kendi hesabına çalışan, işveren, işsiz ve çalışmayan bireylerin toplam katılımcılar içindeki payı ise \%17,3’tür. Katılımcıların büyük bir çoğunluğu lise mezunu veya daha yüksek düzeyde bir eğitime sahiptir. Eğitim düzeyi liseden düşük olan katılımcıların oranı ise yaklaşık \%8'dir. Bireylerin hane halkı geliri bakımından dağılımı incelendiğinde, katılımcıların yaklaşık \%60’1 1600 ile 5000 TL aralığında aylık gelire sahiptir. 1600 TL'nin altında gelire sahip bireylerin katılım oranı \%8,3 iken, 5000 TL'nin üstünde gelire sahip bireylerin katılım oranı ise \%31,8'dir. Katılımcıların yarıdan fazlası bakmakla yükümlü olduğu kimse olmadığını, yaklaşık \%30’u ise bir ya da iki kişiye bakmakla yükümlü olduğunu belirtmiştir.

Ankete katılan bireylerin büyük çoğunluğu eski sistemde SSK ya da Emekli Sandığı'na tabi olduklarını belirtmiştir. Bireylere herhangi bir sağlık sorunu oluştuğunda gitmeyi düşündükleri ilk sağlık kurumunun hangisi olduğu sorulduğunda, yaklaşık \%70’i kamu kurumlarını tercih edeceğini yaklaşı \%30’u ise özel hastane veya muayenehaneleri tercih edeceğini belirtmiştir. Katılımcıların son bir yıl içinde sağlık kurumlarına gitme sıklıkları incelendiğinde ise \%3,2'si hiç gitmediğini, \%49,1'i en fazla beş kere, \%24,6’s1 6 ila 10 kez, \%23'ü ise 10'dan fazla kez gittiğini belirtmiştir.

\subsection{Analize Yönelik Anket Sorularının Frekans Dağılımları}

Anket formunda bireylerin devlet hastanelerindeki hizmet kalitesi ile ilgili görüşlerini değerlendirmek amacıyla; hastanelerdeki yoğunluk, muayene kolaylı̆̆ı, muayene sürelerinin yeterliliği, hekimlerin hastalara yeterli ilgiyi gösterip göstermediği gibi sorular yanında aynı zamanda sağlık hizmetinden genel anlamda memnun olup olmadıkları, hizmeti hızlı ve etkin bulup bulmadıklarına ilişkin soru ve ifadeler yöneltilmiştir. Randevu sisteminde yapılan düzenlemelerin etkisini değerlendirmek amacıyla; istedikleri tarihe randevu alıp alamadıkları, istedikleri hekime ulaşıp ulaşamadıkları ve genel olarak randevu sisteminden memnun olup olmadıklarına ilişkin, hekimler açısından getirilen tam gün yasası ve performansa dayalı ücretlendirme uygulamalarının hastalar açısından olumlu görülüp görülmediğini ölçmek amacıyla; performans ücretlendirmesinin hastaların yararına olup olmadığı, tam gün yasasının ise sağlık hizmetini iyileştirip iyileştirmediğine ilişkin soru ve ifadeler yöneltilmiştir. Sağlık hizmetinin finansmanında öngörülen değişikliklerin hastalar nezdindeki yansımalarını değerlendirmek amacıyla; sosyal güvenlik kurumlarının birleştirilmesiyle eşit hizmet alımının sağlanıp sağlanmadığına yönelik, katılım payı uygulamasının etkilerini değerlendirmek için 
ise; bu uygulamanın hastanelerdeki yoğunluğu azaltıp azaltmadığı, hizmetten faydalanmaya engel teşkil edip etmediği, uygulamanın şeffaf ve güvenilir görülüp görülmediği ve hastaları acil servisleri tercih etmeye yönlendirip yönlendirmediğine ilişkin soru ve ifadeler yöneltilmiştir. Özel hastanelerde hastalara muayene kolaylığı getirilmesini öngören düzenlemeleri değerlendirmek amacıyla; bireylerin özel hastaneleri tercih edip etmediği, ek ücretlerin yüksek olması durumunda yine de tercih edip etmeyeceği, farklı hastanelerde farklı tutarlarda ek ücret uygulamasına ilişkin görüşlerinin ne yönde olduğu ve özel hastanelerde gereksiz tetkik ve işlem yapıldığını düşünüp düşünmediklerine ilişkin soru ve ifadeler, sağlık hizmeti talep eden hastaların aile hekimlikleri ile ilgili değerlendirmelerini ölçmek amacıyla; bu uygulamanın devlet hastanelerindeki yoğunluğu azaltıp azaltmadığı, henüz uygulamaya geçirilmemiş olsa da programın esas hedeflerinden biri aile hekimliğinden sevk alma zorunluluğu getirilerek devlet hastanelerindeki yoğunluğu azaltmak olduğundan, bireylere eğer sevk alma zorunluluğu getirilirse hastalıklarının teşhis ve tedavisi ile ilgili endişe yaratıp yaratmayacağı, ek ücret ödemek zorunda kalsalar da aile hekimliğini atlayarak devlet hastanesine gitmeyi tercih edip etmeyeceği ve sevk uygulamasının devlet hastanelerindeki yoğunluğu azaltıp azaltmayacağına ilişkin soru ve ifadeler yöneltilmiştir. Araştırmaya katılan bireylerin 25 anket sorusuna verdikleri cevapların frekans dağılımları Tablo 2'de yer almaktadır.

Tablo 2: Anket Soruları ve Cevapların Frekans Dağılımları (\%)

\begin{tabular}{|c|c|c|c|c|c|}
\hline & 焉育 & 言 & 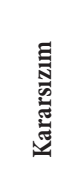 & 咅 & 㲖喜 \\
\hline $\begin{array}{l}\text { 1. Sağlıkta Dönüşüm Programı uygulanmaya başladığından beri devlet } \\
\text { hastanelerinde muayene olmam kolaylaştı. }\end{array}$ & 23,6 & 20,9 & 17,6 & 29,3 & 8,6 \\
\hline $\begin{array}{l}\text { 2. Sağlikta Dönüşüm Programı sonrasında devlet hastanelerinin hizmet } \\
\text { kalitesi artmıştır. }\end{array}$ & 24,1 & 22,3 & 22,1 & 24,8 & 6,7 \\
\hline $\begin{array}{l}\text { 3. Sağlıkta Dönüşüm Programı sonrasında devlet hastanelerindeki yoğunluk } \\
\text { azalmıştır. }\end{array}$ & 33,1 & 34,2 & 13,3 & 16 & 3,4 \\
\hline $\begin{array}{l}\text { 4. Sosyal güvenlik kurumlarının } \\
\text { birleştirilmesiyle herkesin sağlık } \\
\text { sağlanmıştır. }\end{array}$ & 19,4 & 18 & 20,3 & 30,8 & 11,5 \\
\hline $\begin{array}{l}\text { 5. Katılim pay1 uygulaması (Muayene sebebiyle eczanede kesilen para) } \\
\text { gereksiz yere devlet hastanelerine gidilmesini engellemektedir. }\end{array}$ & 25,4 & 23 & 21,9 & 21,4 & 8,3 \\
\hline $\begin{array}{l}\text { 6. Devlet hastanelerindeki yoğunluk sebebiyle ek ücret ödeyerek özel } \\
\text { hastaneye gitmeyi tercih ederim. }\end{array}$ & 10,1 & 16,4 & 18,9 & 30 & 24,6 \\
\hline 7. Aldığım randevu saatinde beklemeden muayene oluyorum. & 26,3 & 25,5 & 16 & 24,1 & 8,1 \\
\hline 8. Devlet hastanesinde tedavimi takip eden hekime her zaman ulaşabiliyorum. & 37,1 & 28,8 & 18,2 & 12,6 & 3,4 \\
\hline $\begin{array}{l}\text { 9. Merkezi Hekim Randevu Sistemi (MHRS) ile devlet hastanelerinde } \\
\text { istediğim tarihe rahatllkla randevu alabiliyorum. }\end{array}$ & 37,1 & 27,9 & 11,7 & 17,6 & 5,8 \\
\hline $\begin{array}{l}\text { 10. Sağlıkta Dönüşüm Programı uygulanmaya başladığından beri sağlık } \\
\text { hizmetlerinden hızlı ve etkin bir şekilde faydalanabilmekteyim. }\end{array}$ & 24,8 & 29,9 & 22,7 & 18,9 & 3,8 \\
\hline
\end{tabular}


Tablo 2 (Devamı): Anket Soruları ve Cevapların Frekans Dağılımları (\%)

\begin{tabular}{|c|c|c|c|c|c|}
\hline & 竞竞 & 声 & 声 & 声 & 美言 \\
\hline $\begin{array}{l}\text { 11. Eczanelerde alınan muayene katılım payı ve ilaç katılım payı ücretlendirmesini } \\
\text { șeffaf ve güvenilir buluyorum. }\end{array}$ & 34,9 & 24,5 & 21,9 & 13,7 & 5 \\
\hline $\begin{array}{l}\text { 12. Aile hekimliği uygulaması başladığından beri devlet hastaneleri eskisi kadar } \\
\text { yoğun değil. }\end{array}$ & 31,7 & 29,1 & 18 & 17,6 & 3,6 \\
\hline 13. Devlet hastanelerindeki hasta muayenesine yeterli süre ayrılmaktadır. & 41 & 24,6 & 13,8 & 16,2 & 4,3 \\
\hline $\begin{array}{l}\text { 14. Katılım payı uygulaması devlet hastanelerindeki sağlık hizmetinden } \\
\text { faydalanmamı engellemektedir. }\end{array}$ & 13,8 & 30,6 & 27,9 & 21,8 & 5,9 \\
\hline $\begin{array}{l}\text { 15. Aile hekiminden sevk alma zorunluluğu getirilirse, devlet hastanelerindeki } \\
\text { yoğunluk azalır böylece devlet hastanesinden daha etkin bir sağllk hizmeti alırım. }\end{array}$ & 21,6 & 25,2 & 19,6 & 24,8 & 8,8 \\
\hline $\begin{array}{l}\text { 16. Aile hekiminden sevk alma zorunluluğu getirilirse, sevk almadan doğrudan } \\
\text { devlet hastanesine gittiğim zaman daha yüksek katılım payı ödesem de devlet } \\
\text { hastanesine gitmeyi tercih ederim. }\end{array}$ & 23,9 & 25,7 & 25,9 & 17,3 & 7,2 \\
\hline $\begin{array}{l}\text { 17. Devlet hastanelerinde hekimlerin baktığı hasta sayısına göre (performansa } \\
\text { göre) ücret almaları hastaların yararınadır. }\end{array}$ & 43 & 21,2 & 13,5 & 16,2 & 6,1 \\
\hline $\begin{array}{l}\text { 18. Hekimlerin hem devlet hastanelerinde çalıșıp hem özel muayenehane } \\
\text { açmalarının engellenmesi, muayenehanelerinin kapatılmasıyla sağlık hizmetinin } \\
\text { iyileștiğini düşünüyorum. }\end{array}$ & 19,4 & 22,3 & 21,2 & 25 & 12,1 \\
\hline 19. Katılım payı ödemediğim için acil servisi tercih ederim. & 22,3 & 32,2 & 20,5 & 18,2 & 6,8 \\
\hline $\begin{array}{l}\text { 20. Aile hekiminden sevk alma zorunluluğu getirilirse, hastalığımın teşhis ve } \\
\text { tedavisinde yetersiz kalma endișesi yaratmaktadır. }\end{array}$ & 8,3 & 13,8 & 25,5 & 33,3 & 19,1 \\
\hline $\begin{array}{l}\text { 21. Özel hastanelerde gereksiz tetkik ve işlemler yapıldığını düşündüğümden özel } \\
\text { hastaneleri tercih etmiyorum. }\end{array}$ & 12,1 & 20,3 & 19,2 & 30,2 & 18,2 \\
\hline $\begin{array}{l}\text { 22. Özel hastaneler arasında farklı tutarlarda ek ücret alınması sağlık hizmetine } \\
\text { erișimi olumsuz yönde etkilemektedir. }\end{array}$ & 8,8 & 9,7 & 10,6 & 38,5 & 32,4 \\
\hline $\begin{array}{l}\text { 23. Devlet hastanelerindeki yoğunluğa ve muayene süresinin kısalığına rağmen } \\
\text { özel hastanelerde ek ücretlerin yüksek olması sebebiyle özel hastaneleri tercih } \\
\text { etmem. }\end{array}$ & 14 & 24,5 & 23,4 & 27,2 & 11 \\
\hline \begin{tabular}{|l|} 
24. Sağlıkta Dönüşüm Programı uygulanmaya başladığından beri devlet \\
hastanelerindeki hekimlerin hastalarla daha fazla ilgilendiğini düșünüyorum.
\end{tabular} & 32,9 & 26,1 & 22,7 & 14,7 & 3,6 \\
\hline $\begin{array}{l}\text { 25. Sağlıkta Dönüşüum Programı genel olarak sağlık hizmetinden faydalanmamı } \\
\text { olumlu etkilemiştir. }\end{array}$ & 25,4 & 17,3 & 27,2 & 23,9 & 6,3 \\
\hline
\end{tabular}

Tablo 2'de yer alan ve Sağlıkta Dönüşüm Programı sonrası İstanbul'da sağlık hizmetinden memnuniyeti göstermek bakımından özellikle önem arz eden 11 ifadeye ilişkin katılımcıların düşünceleri aşağıda özetlenmiştir;

"Sağlıkta Dönüşüm Programı uygulanmaya başladığından beri devlet hastanelerinde muayene olmam kolaylaştı” ifadesine; toplam \%37,6’sı katılıyorum/kesinlikle katılıyorum, toplam \%44,5’i ise katılmıyorum/kesinlikle katılmıyorum şeklinde,

"Sağlıkta Dönüşüm Programı sonrasında devlet hastanelerinin hizmet kalitesi artmıştır" ifadesine; toplam \%31,5’i katılıorum/kesinlikle katılıorum, toplam \%46,4'ü ise katılmıorum/ kesinlikle katılmıyorum şeklinde, 
"Katılım payı uygulaması (Muayene sebebiyle eczanede kesilen para) gereksiz yere devlet hastanelerine gidilmesini engellemektedir” ifadesine; toplam \%29,7'si katıllyorum/kesinlikle katılıyorum, toplam \%48,4’ü ise katılmıyorum/ kesinlikle katılmıyorum şeklinde,

"Aldığım randevu saatinde beklemeden muayene oluyorum" ifadesine; toplam \%32,2'si katılıorum/kesinlikle katılıyorum, toplam \%51,8'si katılmıyorum/kesinlikle katılmıyorum şeklinde,

"Devlet hastanesinde tedavimi takip eden hekime her zaman ulaşabiliyorum" ifadesine; toplam \%16'sı katılıyorum/kesinlikle katılıyorum, toplam \%65,9'u ise katılmıyorum/kesinlikle katılmıyorum şeklinde,

"Merkezi Hekim Randevu Sistemi (MHRS) ile devlet hastanelerinde istediğim tarihe rahatlıkla randevu alabiliyorum" ifadesine; \%23,4'ü katılıyorum/kesinlikle katılıyorum, \%65'i katılmıyorum/ kesinlikle katılmıyorum şeklinde,

"Devlet hastanelerinde hekimlerin baktığı hasta sayısına göre (performansa göre) ücret almaları hastaların yararınadır” ifadesine; toplam \%22,3’ü katılıyorum/kesinlikle katılıyorum, toplam \%64,2’si katılmıorum/kesinlikle katılmıyorum şeklinde,

"Hekimlerin hem devlet hastanelerinde çalışıp hem özel muayenehane açmalarının engellenmesi, muayenehanelerinin kapatılmasıyla sağlık hizmetinin iyileştiğini düşünüyorum” ifadesine; \%37,1 katılıyorum/kesinlikle katılıyorum, toplam \%41,7'si katılmıyorum/kesinlikle katılmıyorum şeklinde,

"Özel hastanelerde gereksiz tetkik ve işlemler yapıldığını düşündügüumden özel hastaneleri tercih etmiyorum” ifadesine; toplam \%48’ 4 ü katılıyorum/kesinlikle katılıyorum, toplam \%32,4’ü katılmıyorum/kesinlikle katılmıyorum şeklinde,

"Özel hastaneler arasında farklı tutarlarda ek ücret alınması sağlık hizmetine erişimi olumsuz yönde etkilemektedir” ifadesine; toplam \%18,3'ü katılıyorum/kesinlikle katılıyorum, toplam \%59'u katılmıyorum/kesinlikle katılmıyorum şeklinde,

"Sağlıkta Dönüşüm Programı genel olarak sağlık hizmetinden faydalanmamı olumlu etkilemiştir" ifadesine; toplam \%30'si katılıyorum/kesinlikle katılıyorum, toplam \%42,7'si ise katılmıorum/ kesinlikle katılmıyorum şeklinde cevap vermişlerdir.

\subsection{Hipotez Testleri}

Çalışmanın bu bölümünde, çeşitli bağımsız değişkenler göz önünde bulundurularak bireylerin sağlık hizmetinden memnuniyetini etkileyen faktörlerin kendi aralarında istatistiksel açıdan anlamlı bir farklılık olup olmadığı incelenmiştir. İki bağımsız grup için t testi ve ikiden fazla bağımsız grup için ise Tek Yönlü Varyans Analizi (ANOVA) uygulanmıştır. 


\subsection{I. t Testi Sonuçları}

Cinsiyet, eğitim, medeni durum ve son bir yıl içerisinde sağlık kurumuna başvurma sayıları değişkenlerine göre üç farklı memnuniyet (sağlık hizmetine duyulan genel memnuniyet, katılım payı uygulamasına duyulan memnuniyet ve sağlık hizmetinde randevu sistemi ve muayene sürelerine ilişkin memnuniyet) açısından farklılıkların incelenmesi amacıyla yapılan $t$ testi sonuçlarına ilişkin bulgular Tablo 3’te özetlenmiştir.

Tablo 3: Cinsiyet, Eğitim Düzeyi, Medeni Durum ve Sağlık Kurumuna Başvurma Sıklığına Göre

Memnuniyet Açısından Farklııılara İlişkin Test Sonuçları

\begin{tabular}{|c|c|c|c|c|c|c|c|c|}
\hline \multirow[b]{2}{*}{ Memnuniyet } & \multicolumn{2}{|l|}{ Cinsiyet } & \multicolumn{2}{|l|}{ Eğitim } & \multicolumn{2}{|c|}{ Medeni Durum } & \multicolumn{2}{|c|}{ Başvuru Sayısı } \\
\hline & 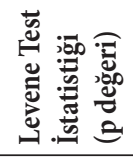 & 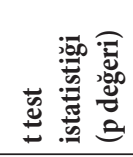 & 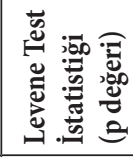 & 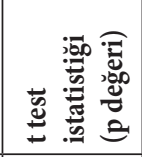 & 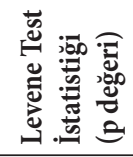 & 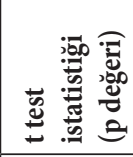 & 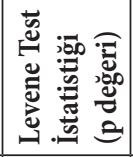 & 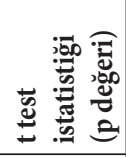 \\
\hline $\begin{array}{l}\text { Sağlık } \\
\text { Hizmetleri }\end{array}$ & $\begin{array}{l}13,339 \\
(0,000)\end{array}$ & $\begin{array}{l}-2,209 \\
(0,028)\end{array}$ & $\begin{array}{l}0,045 \\
(0,833)\end{array}$ & $\begin{array}{l}3,746 \\
(0,000)\end{array}$ & $\begin{array}{l}0,690 \\
(0,407)\end{array}$ & $\begin{array}{l}0,938 \\
(0,349)\end{array}$ & $\begin{array}{l}0,394 \\
(0,531)\end{array}$ & $\begin{array}{l}2,31 \\
(0,021)\end{array}$ \\
\hline $\begin{array}{l}\text { Katılım Payı } \\
\text { Uygulaması }\end{array}$ & $\begin{array}{l}5,286 \\
(0,022) \\
\end{array}$ & \begin{tabular}{|l|}
$-1,325$ \\
$(0,186)$ \\
\end{tabular} & \begin{tabular}{|l|}
1,982 \\
$(0,160)$
\end{tabular} & \begin{tabular}{|l|}
3,32 \\
$(0,001)$
\end{tabular} & \begin{tabular}{|l|}
5,169 \\
$(0,023)$ \\
\end{tabular} & \begin{tabular}{|l|}
$-1,485$ \\
$(0,138)$ \\
\end{tabular} & \begin{tabular}{|l|}
0,001 \\
$(0,980)$ \\
\end{tabular} & \begin{tabular}{|l|}
3,877 \\
$(0,000)$
\end{tabular} \\
\hline $\begin{array}{l}\text { Randevu Sistemi } \\
\text { ve Muayene } \\
\text { Süreleri }\end{array}$ & $\begin{array}{l}11,142 \\
(0,001)\end{array}$ & $\begin{array}{l}-3,145 \\
(0,002)\end{array}$ & $\begin{array}{l}3,544 \\
(0,060)\end{array}$ & $\begin{array}{l}2,570 \\
(0,010)\end{array}$ & $\begin{array}{l}0,770 \\
(0,381)\end{array}$ & $\begin{array}{l}0,567 \\
(0,571)\end{array}$ & $\begin{array}{l}, 825 \\
(0,177)\end{array}$ & $\begin{array}{l}3,237 \\
(0,001)\end{array}$ \\
\hline
\end{tabular}

Testin varsayımlarından biri olan homojenlik varsayımı her 3 memnuniyet durumu için Levene testi ile incelenmiştir.

Hipotezler;

$\boldsymbol{H}_{0}$ : İlgili demografik değişkenlerinin memnuniyet değerlerinin varyansları eşittir.

$\boldsymbol{H}_{1}$ : İlgili demografik değişkenlerinin memnuniyet değerlerinin varyansları eşit değildir.

Tüm testlerde sonuçlar \%5 anlam düzeyine göre incelenmiş olup, varyansların eşit olup olmadığ1 göz önünde bulundurularak sonrasinda kurulan hipotezler;

$\boldsymbol{H}_{0}$ : İlgili demografik özelliğin grupları arasında memnuniyet değerlerinin ortalamaları eşittir.

$\boldsymbol{H}_{1}$ : İlgili demografik özelliğin grupları arasında memnuniyet değerlerinin ortalamaları eşit değildir.

Cinsiyete göre yapılan $\mathrm{t}$ testi sonuçları incelendiğinde; kadın ve erkekler arasında sağlık hizmetine duyulan memnuniyet seviyelerinin birbirinden farklı olduğu bulunmuştur $(t(408,092)=-2,209 ; p=0,028)$. Buna göre ortalamalara bakıldığında erkeklerin sağlık hizmetine duyduğu ıemnuniyet kadınların memnuniyetinden anlamlı derecede fazladır $\left(\mu_{\text {kadın }}=15,99\right.$, $\left.s s=5,106 ; \mu_{\text {erkek }}=17,09, s s=06,131\right)$. Kadın ve erkekler arasında katılım payı uygulamasına duyulan memnuniyet seviyelerinin arasında istatistiksel açıdan anlamlı bir fark olmadığı tespit edilmiştir 
$(t(41,037)=-1,325 ; p=0,186)$. Kadın ve erkekler arasında sağlık hizmetinde uygulanan randevu sistemi ve muayene sürelerine ilişkin memnuniyet açısından istatistiksel açıdan anlamlı bir fark vardır $(t(407,196)=-3,145 ; p=0,002)$. Erkeklerin randevu ve muayene sürelerine duydukları memnuniyet kadınların memnuniyetinden anlamlı derecede fazladır $\left(\mu_{\text {kadın }}=11,50, s s=4,305\right.$; $\left.\mu_{\text {erkek }}=12,83, s s=5,183\right)$.

Tablo. 3’te görüldüğü gibi, medeni durumlar (Evli ve Bekar) arasında memnuniyet değerlerinin ortalamaları arasında fark olup olmadığ $\mathrm{t}$ testi ile incelendiğinde, gruplar arasında anlamlı farkın olmadı̆̆ 1 (p değeri $>0,05$ ) sonucu elde edilmiştir.

Eğitim seviyesine (lisans öncesi mezuniyet (a) - lisans ve lisansüstü mezuniyet(b)) göre yapılan $\mathrm{t}$ testi sonuçları incelendiğinde; gruplar arasında sağlık hizmetine duyulan memnuniyet $(t(554)=3,746 ; p=0,000)$, katılım payı uygulamasina duyulan memnuniyet $(t(554)=3,320$; $p=0,001)$ ve sağlık hizmetinde randevu sistemi ve muayene sürelerine ilişkin memnuniyet $(t(554)=2,570 ; p=0,010)$ açısından anlamlı fark olduğu tespit edilmiştir. Lisans öncesi mezuniyete sahip olan bireylerin sağlık hizmetine $\left(\mu_{\mathrm{a}}=17,39, s s=5,625 ; \mu_{\mathrm{b}}=15,64, s s=5,380\right)$, katılım pay1 uygulamasina $\left(\mu_{\mathrm{a}}=13,33, s s=3,44 ; \mu_{\mathrm{b}}=12,40, s s=3,12\right)$ ve randevu sistemi - muayene sürelerine duyulan memnuniyetleri $\left(\mu_{\mathrm{a}}=12,59, s s=4,98 ; \mu_{\mathrm{b}}=11,57, s s=4,43\right)$ lisans ve lisansüstü mezuniyete sahip olan bireylerin memnuniyetinden anlamlı derecede fazladır.

Son 1 yıl içerisinde sağlık kurumuna başvurma sayısına (en fazla 5 (a), 5 ’ten fazla (b)) göre sağlık hizmetinden duyulan memnuniyet $(t(554)=2,310 ; p=0,021)$, katılım payı uygulamasından duyulan memnuniyet $(t(554)=3,877 ; p=0,000)$ ve sağlik hizmetinde randevu sistemine ve muayene sürelerine ilişkin memnuniyet $(t(554)=3,237 ; p=0,001)$ açısından anlamlı farklar bulunduğu tespit edilmiştir. En fazla beş kere sağlık kurumuna başvuran bireylerin sağlık hizmetine $\left(\mu_{\mathrm{a}}=16,94, s s=5,46 ; \mu_{\mathrm{b}}=15,85, s s=5,628\right)$, katılım payı uygulamasina $\left(\mu_{\mathrm{a}}=13,333\right.$, $\left.s s=3,245 ; \mu_{\mathrm{b}}=12,260, s s=3,274\right)$ ve randevu sistemi ile muayene sürelerine duydukları memnuniyet seviyesi $\left(\mu_{\mathrm{a}}=12,64, s s=4,803 ; \mu_{\mathrm{b}}=11,35\right.$, ss=4,525), sağlık kurumlarına beş kereden fazla başvuranların memnuniyet seviyelerinden anlamlı derecede öndedir.

\subsubsection{Varyans Analizi (ANOVA) Sonuçları}

Yaş, gelir düzeyi ve bakmakla yükümlü olunan kişi sayıları değişkenlerine göre üç farklı memnuniyet (sağlık hizmetine duyulan genel memnuniyet, katılım payı uygulamasına duyulan memnuniyet ve sağlık hizmetinde randevu sistemi ve muayene sürelerine ilişkin memnuniyet) açısından farklılıkların incelenmesi amacıyla yapılan Varyans Analizi sonuçlarına ilişkin bulgular Tablo 4’te özetlenmiştir. 
Tablo 4: Yaş, Gelir Düzeyi ve Bakmakla Yükümlü Olunan Kişi Sayısına Göre Memnuniyet Açısından Grup Ortalamaları Arasındaki Farklılıklara İlişkin Test Sonuçları

\begin{tabular}{|l|l|l|l|l|l|l|}
\hline \multirow{2}{*}{ Memnuniyet } & \multicolumn{2}{|l|}{ Yaş Grupları } & \multicolumn{2}{l|}{ Gelir Grupları } & \multicolumn{2}{l|}{$\begin{array}{l}\text { Bakmakla Yükümlü Olunan } \\
\text { Kişi Sayısı Grupları }\end{array}$} \\
\cline { 2 - 7 } & $\begin{array}{l}\text { Levene Testi } \\
\text { p değeri }\end{array}$ & $\begin{array}{l}\text { Varyans } \\
\text { Analizi } \\
\text { p değeri }\end{array}$ & $\begin{array}{l}\text { Levene Testi } \\
\text { p değeri }\end{array}$ & $\begin{array}{l}\text { Varyans Analizi } \\
\text { p değeri }\end{array}$ & $\begin{array}{l}\text { Levene Testi } \\
\text { p değeri }\end{array}$ & $\begin{array}{l}\text { Varyans Analizi } \\
\text { p değeri }\end{array}$ \\
\hline Sağlık Hizmetleri & 0,011 & 0,012 & 0,264 & 0,110 & 0,122 & 0,029 \\
\hline $\begin{array}{l}\text { Katılım Payı } \\
\text { Uygulaması }\end{array}$ & 0,798 & 0,02 & 0,318 & 0,098 & 0,017 & 0,819 \\
\hline $\begin{array}{l}\text { Randevu Sistemi ve } \\
\text { Muayene Süreleri }\end{array}$ & 0,775 & 0,022 & 0,048 & 0,095 & 0,215 & 0,038 \\
\hline
\end{tabular}

Testin varsayımlarından biri olan homojenlik varsayımı her 3 memnuniyet durumu için Levene testi ile incelenmiştir.

Hipotezler;

$\boldsymbol{H}_{0}$ : İlgili demografik değişkenlerinin memnuniyet değerlerinin varyansları eşittir.

$\boldsymbol{H}_{1}$ : İlgili demografik değişkenlerinin memnuniyet değerlerinin varyansları eşit değildir.

Tüm testlerde sonuçlar \%5 anlam düzeyine göre incelenmiş olup, varyansların eşit olup olmadığ göz önünde bulundurularak sonrasında kurulan hipotezler;

$\boldsymbol{H}_{0}$ : İlgili demografik özelliğin grupları arasında memnuniyet değerlerinin ortalamaları eşittir.

$H_{1}$ : En az bir grubun memnuniyet değerlerinin ortalamaları farklıdır.

Sağlık hizmetine duyulan memnuniyet ve katılım payı uygulamasına duyulan memnuniyetin gelir seviyelerine göre farklılık gösterip göstermediğini test etmek için yapılan tek yönlü varyans analizi sonucu \%95 güven aralı̆̆ında gelir seviyeleri arasında istatistiksel olarak anlamlı bir fark bulunamamıştır. Ayrıca farklı gelir gruplarına sahip bireylerin sağlık hizmetinde randevu ve muayene sürelerine ilişkin memnuniyetlerinin eşitliği test edilmek istendiğinde, grupların eşit varyansa sahip olmadıkları Levene testiyle tespit edilmiştir. Bu durumda tek yönlü ANOVA testinin ön şartı sağlanamamış olup ANOVA testi yerine Welch testi yapılmıştır. Welch testi sonucunda gelir grupları arasında istatistiksel olarak anlamlı bir fark olmadığı tespit edilmiştir.

Bakmakla yükümlü olunan kişi sayısına göre sağlık hizmetine duyulan memnuniyetin ve randevu sistemi ile muayene sürelerine duyulan memnuniyetin eşit olup olmadığ tek yönlü varyans analizi ile incelendiğinde, kimseye bakmakla yükümlü olmayanlar, 1-2 kişiye bakmakla yükümlü olanlar ve 3 ve 3 ’ten fazla kişiye bakmakla yükümlü olanlar arasında istatistiksel olarak anlamlı bir fark olduğu bulunmuştur. Bu farkın hangi grup seviyesindeki bireylerden kaynaklandığını tespit edebilmek için Tukey testi sonuçlarına bakılmıştır. Tukey testi sonucunda 3 ve 3’ten fazla kişiye bakmakla yükümlü olan bireylerin, 1-2 kişiye bakmakla yükümlü olan bireylere göre her iki memnuniyet hususunda da daha memnun oldukları görülmüştür (Sağlık Hizmeti: $\mu_{3-33^{\prime} \text { ten fazla }}=17,82, \mu_{1-2 \text { kiși }}=15,99$; Randevu ve 
Muayene Süresi: $\left.\mu_{3-3^{3} \operatorname{ten~fazla~}}=13,18, \mu_{1-2 \text { kiși }}=11,70\right)$. Fakat söz konusu üç grup arasında katılım payı uygulamasına duyulan memnuniyetlerin eşitliği test edilmek istendiğinde, grupların eşit varyansa sahip olmadıkları Levene testiyle tespit edilmiştir. Bu durumda tek yönlü ANOVA testinin ön şartı sağlanamamıştır ve bunun yerine Welch testi yapılmıştır. Welch testi sonucunda gruplar arasında istatistiksel olarak anlamlı bir fark bulunamamıștır.

Tablo 5: Bakmakla Yükümlü Olunan Kişi Sayılarına Göre Memnuniyetin Çoklu Karşış̧̧ırma (Post Hoc) Test Sonuçları

\begin{tabular}{|l|l|l|l|l|}
\hline \multicolumn{2}{|l|}{ Bakmakla Yükümlï Olunan Kişi Sayısı } & $\begin{array}{l}\text { Sağlık Hizmetleri p } \\
\text { değeri }\end{array}$ & $\begin{array}{l}\text { Sağlık Hizmetinde Randevu Sistemi ve } \\
\text { Muayene Süreleri p değeri }\end{array}$ \\
\hline \multirow{4}{*}{ Tukey HSD } & \multirow{2}{*}{ Yok } & $\mathbf{1 - 2}$ & 0,891 & 0,933 \\
\cline { 2 - 5 } & \multirow{2}{*}{$\mathbf{1 - 2}$} & Y'den fazla & 0,046 & 0,053 \\
\cline { 2 - 5 } & \multirow{2}{*}{ 3'den fazla } & Yok fazla & 0,891 & 0,933 \\
\cline { 3 - 5 } & & $\mathbf{1 - 2}$ & 0,031 & 0,043 \\
\cline { 3 - 5 } & & 0,031 & 0,053 \\
\hline
\end{tabular}

Farklı yaş gruplarının sağlık hizmetine duydukları memnuniyetin eşit olup olmadığı incelendiğinde grupların eşit varyansa sahip olmadıkları Levene testi ile tespit edilmiştir. Bu durumda tek yönlü ANOVA testinin ön şartı yerine getirilememiştir. ANOVA testi yerine Welch testi yapılmıştır. Welch testi sonucunda gruplar arasında istatistiksel olarak anlamlı bir fark ortaya çıkarılmıștır. Bu farkın hangi gruplardan kaynaklandığını tespit etmek için Tamhane $\mathrm{T}^{2}$ testi sonuçlarına bakılmıştır. Tablodan görüleceği gibi, 18-25 yaşları arasır laki bireyler sa lık hizmetinden 26-35 yaşları arasındaki bireylere göre daha memnundurlar $\left(\mu_{18-25 \text { yaş }}=17,68, \mu_{26-}\right.$ 35 yaş $=15,65)$.

Tablo 6: Yaşa Göre Memnuniyetin Post Hoc Test Sonuçları

\begin{tabular}{|c|c|c|c|c|}
\hline \multicolumn{2}{|l|}{ YAŞ } & $\begin{array}{l}\text { Sağlık Hizmeti } \\
\text { Tamhane p değeri }\end{array}$ & $\begin{array}{l}\text { Katılım Payı } \\
\text { Uygulaması Tukey p } \\
\text { değeri }\end{array}$ & $\begin{array}{l}\text { Sağlık Hizmetinde Randevu } \\
\text { Sistemi ve Muayene Süreleri Tukey } \\
\text { p değeri }\end{array}$ \\
\hline \multirow{3}{*}{$18-25$ yaş } & 26-35 yaş & 0,003 & 0,025 & 0,037 \\
\hline & $36-45$ yaş & 0,059 & 0,069 & 0,757 \\
\hline & 46 yaş üstü & 0,964 & 0,791 & 1,000 \\
\hline \multirow{3}{*}{$26-35$ yaş } & $18-25$ yaş & 0,003 & 0,025 & 0,037 \\
\hline & $36-45$ yaş & 1,000 & 0,999 & 0,367 \\
\hline & 46 yaş üstü & 1,67 & 0,393 & 0,071 \\
\hline \multirow{3}{*}{$36-45$ yaş } & $18-25$ yaş & 0,059 & 0,069 & 0,757 \\
\hline & $26-35$ yaş & 1,000 & 0,999 & 0,367 \\
\hline & 46 yaş üstü & 0,419 & 0,542 & 0,807 \\
\hline \multirow{3}{*}{46 yaş üstü } & $18-25$ yaş & 0,964 & 0,791 & 1,000 \\
\hline & $26-35$ yaş & 0,167 & 0,393 & 0,071 \\
\hline & $36-45$ yaş & 0,419 & 0,542 & 0,807 \\
\hline
\end{tabular}


Farklı yaş gruplarının katılım payı uygulamasından ve randevu sistemi ile muayene sürelerinden memnuniyet seviyelerinin eşit olup olmadığı incelendiğinde, Levene testi ile varyanslarının eşit olduğu görülerek tek yönlü ANOVA testine geçilmiştir. Tek yönlü varyans analizinde yaş grupları arasında istatistiksel olarak anlamlı memnuniyet farkları olduğu belirlenmiştir. Bu farkın hangi gruplardan ileri geldiğini bulmak için yapılan Tukey testi sonucunda, 18-25 yaşları arasındaki bireylerin, 26-35 yaşları arasındaki bireylere göre, hem katılım payı uygulamasından hem de randevu sistemi ile muayene sürelerinden daha yüksek oranda memnun oldukları saptanmıştır (Katılım Payı: $\mu_{18-25 \text { yaş }}=13,50, \mu_{26-}$ 35 yaş $=12,45$; Randevu ve Muayene Süresi: $\left.\mu_{18-25 \text { yas }}=12,67, \mu_{26-35 \text { yaş }}=11,24\right)$.

\section{Sonuç}

Türkiye'de 2003 yılı itibarıyla uygulamaya geçirilen Sağlıkta Dönüşüm Programı ile sağlık hizmetinin sunumu ve sağlı hizmetinin finansmanı alanında bir dizi yeni uygulama hayata geçirilmiştir. Bu uygulamaların sağlık sistemine getirdiği yenilikler ve değişikliklerin sağlık hizmeti talep eden hastalar üzerindeki etkisini değerlendirmek amacıyla İstanbul düzeyinde bireylerin sağlık hizmetinden memnuniyetini ölçmeye yönelik anket araştırması gerçekleştirilmiştir. 720 kişi ile yapılan anketten eksiksiz ve anlamlı olan 556'sı analize alınmıştır. Anketlere verilen cevapların frekans dağılımları incelendiğinde sağlık hizmetinden memnuniyete ilişkin yapılan tespitler şu şekildedir:

-Sağlıkta Dönüşüm Programının genel olarak sağlık hizmetinden faydalanmayı kolaylaştırmadığ1 düşüncesinin hakim olduğu görülmüştür. Zira katılımcıların \%30’u programın sağlık hizmetinden faydalanmayı olumlu etkilediğini, \%42,7’si ise buna katılmadığını belirtmiş, yine katılımcıların \%31,5’i devlet hastanelerinde muayenenin kolaylaştığını \%46,4’ü ise buna katılmadığını belirtmişlerdir.

-Katılım payı uygulaması bu haliyle sağlık hizmetinden memnuniyeti azaltan bir durum olarak görülmemektedir. Zira katılımcıların \%29,7'si katılım payı uygulamasının devlet hastanelerine gidilmesini engellediğini, \%48,4’ü ise buna katılmadığını ifade etmiştir.

-Sağlık hizmetine kavuşmak ve faydalanmak bakımından, merkezi randevu sistemindeki aksaklıklar ile tedaviyi takip eden doktora ulaşmadaki sorunların sağlık hizmetinden memnuniyet oranını düşürdüğü görülmüştür. Zira katılımcıların \%22,3’ü Merkezi Hekim Randevu Sisteminden kolayca randevu aldığını, \%65’i ise alamadığını, \%32,2 'si randevu saatinde beklemeden muayene olabildiğini, \%51,8'si ise olamadığını, \%16’sı devlet hastanesinde tedaviyi takip eden doktora kolaylıkla ulaşabildiğini, \%65,9’u ise ulaşamadığını ifade etmiştir.

- Katılımcıların \%22,3’ü performansa dayalı ücret uygulamasını hasta yararına bulduğu, \%64,2’sinin ise buna katılmadığı görülmüştür.

- Katılımcıların önemli bir bölümünün özel hastaneleri gereksiz tetkik ve işlem yaptıkları için tercih etmedikleri görülmüştür. Nitekim katılımcıların, \%48,4’ü özel hastanelerde gereksiz tetkik 
ve işlem yapıldığını düşünerek özel hastaneleri tercih etmeyeceğini belirtirken, \%32,4'ü buna katılmadığını belirtmiştir. Katılımcıların \%18,3’ü özel hastaneler arasındaki fiyat farklılı̆̆ının sağlık hizmetine erişimi olumsuz yönde etkilediğini, \%59’u ise buna katılmadığını ifade etmiştir.

Çalışmada, sağlık hizmetinden memnuniyeti oluşturan faktörlerden; sağlık hizmetine duyulan genel memnuniyet, katılım payı uygulamasına duyulan memnuniyet ve sağlık hizmetinde randevu sistemi ve muayene sürelerine ilişkin memnuniyet analiz edilmiştir. Çeşitli demografik özellikler göz önünde bulundurularak grupların kendi aralarında istatistiksel açıdan anlamlı bir fark olup olmadığı incelenmiştir. Bahsi geçen demografik özelliklerden cinsiyet, medeni durum, eğitim düzeyi ve son bir yıl içinde sağlık kurumlarına başvurma sıklığı bakımından analizlerde bağımsız gruplar t testi uygulanmış; gelir düzeyi, yaş grubu ve bakmakla yükümlü olunan kişi sayısı bakımından ise tek yönlü Varyans Analizi (ANOVA) uygulanmıştır.

Sağlık hizmetine duyulan genel memnuniyet açısından seçilen gruplar arasında fark olup olmadığı analiz edildiğinde; erkek katılımcılar ile kadın katılımcılar arasında istatistiksel açıdan anlamlı bir fark olduğu ve erkeklerin sağlık hizmetine duyduğu memnuniyetin kadınların memnuniyetinden anlamlı derecede daha fazla olduğu ortaya çıkmıştır. Medeni durum bakımından evli ve bekar katılımcılar arasında istatistiksel açıdan anlamlı bir fark olmadığı tespit edilmiştir. Eğitim düzeyleri itibarıla incelendiğinde lisans öncesi eğitim düzeyine sahip olan bireylerin sağlık hizmetine duyduğu memnuniyetin lisans ve lisansüstü mezunu bireylere göre anlamlı derecede daha fazla olduğu tespit edilmiştir. Sağlık kurumlarına gitme sıklığına göre son bir yılda en fazla beş kere sağl1k kurumuna gittiğini belirten bireylerin, beşten fazla gittiğini belirten bireylere kıyasla sağlık hizmetinden daha memnun oldukları görülmüştür. Gelir düzeyi itibarıyla incelendiğinde, farklı gelir grupları arasında sağlık hizmetine duyulan genel memnuniyet açısından istatistiksel olarak anlamlı bir fark olmadığı tespit edilmiştir. Bireylerin bakmakla yükümlü oldukları kişi sayısı itibarıyla incelendiğinde, gruplar arasında istatistiksel olarak anlamlı bir fark olduğu görülmüş, Tukey testi sonuçlarına göre 3’ten fazla kişiye bakmakla yükümlü olan bireylerin, 1-2 kişiye bakmakla yükümlü olanlara göre sağlık hizmetinden daha memnun oldukları ortaya çıkmıştır. Yaş grupları itibarıyla incelendiğinde grupların eşit varyansa sahip olmadığı görülmüş, yapılan Welch testi ile istatistiki açıdan anlamlı bir fark olduğu tespit edilmiş ve Tamhane testi sonuçlarına göre 18-25 yaş aralığındaki bireylerin 26-35 yaş aralığındaki bireylere göre sağlık hizmetinden daha memnun oldukları bulunmuştur.

Katılım payı uygulamasına duyulan memnuniyet açısından seçilen gruplar arasında fark olup olmadığı analiz edildiğinde; cinsiyet ve medeni durum bakımından gruplar arasında istatistiksel açıdan anlamlı bir fark olmadığı görülmüştür. Eğitim düzeyleri bakımından lisans öncesi eğitim düzeyine sahip olan bireylerin lisans ve lisansüstü mezunu bireylere göre katılım payı uygulamasından daha memnun oldukları tespit edilmiştir. Son bir yıl içinde sağlık kurumlarına en fazla beş kere gittiğini belirten bireylerin katılım payı uygulamasına duydukları memnuniyetin, beşten fazla kez gittiğini belirten bireylerin memnuniyetinden anlamlı derecede daha fazla olduğu görülmüştür. Gelir düzeyi bakımından incelendiğinde, katılım payı uygulamasına duyulan memnuniyet açısından farklı gelir grupları arasında istatistiksel olarak anlamlı bir fark olmadı̆̆ı 
ortaya çıkmıştır. Bakmakla yükümlü olunan kişi sayısı bakımından incelendiğinde, grupların eşit varyansa sahip olmadığı görülmekle birlikte yapılan Welch testi ile gruplar arasında istatistiksel olarak anlamlı bir fark bulunmadığı ortaya çıkmıştır. Yaş grupları itibarılyla incelendiğinde grupların varyanslarının eşit olduğu ve gruplar arasında istatistiksel açıdan anlamlı bir fark olduğu tespit edilmiştir. Bu bağlamda Tukey testi yardımıyla 18-25 yaş aralığındaki bireylerin, 26-35 yaş aralığındaki bireylere göre katılım payı uygulamasından daha memnun oldukları tespit edilmiştir.

Sağlık hizmetinde randevu sistemi ve muayene sürelerine ilişkin memnuniyet açısından seçilen gruplar arasında fark olup olmadığı analiz edildiğinde; cinsiyet bakımından yapılan analiz erkek katılımcıların randevu sistemi ve muayene sürelerine duydukları memnuniyetin kadınlardan anlamlı derecede fazla olduğunu ortaya koymuştur. Medeni durum bakımından evli ve bekar katılımcılar arasında istatistiksel açıdan anlamlı bir fark olmadığı tespit edilmiştir. Eğitim düzeyleri bakımından incelendiğinde, lisans öncesi eğitim düzeyine sahip olan bireylerin lisans ve lisansüstü mezunu bireylere göre randevu sistemi ve muayene sürelerinden daha memnun oldukları ortaya çıkmıştır. Sağlık kurumlarına gitme sıklı̆̆ına göre son bir yılda en fazla beş kere sağllk kurumuna gittiğini belirten bireylerin, beşten fazla kez gittiğini belirten bireylere kıyasla randevu sistemi ve muayene sürelerinden daha memnun oldukları görülmüştür. Gelir düzeyi bakımından incelenen gruplar arasında randevu sistemi ve muayene sürelerine ilişkin memnuniyet bakımından istatistiksel olarak anlamlı bir fark olmadığı tespit edilmiştir. Bakmakla yükümlü olunan kişi sayısı bakımından incelendiğinde, gruplar arasında anlamlı bir farklılık olduğu görülmüştür. Tukey testi sonuçlarına göre 3 ten fazla kişiye bakmakla yükümlü olan bireylerin, 1-2 kişiye bakmakla yükümlü olanlara göre randevu sistemi ve muayene sürelerinden daha memnun oldukları ortaya çıkmıştır. Yaş grupları itibarıyla incelendiğinde grupların varyanslarının eşit olduğu ve gruplar arasında istatistiksel açıdan anlamlı bir fark olduğu tespit edilmiştir. Tukey testi sonuçlarına göre 18-25 yaş aralığındaki bireylerin randevu sistemi ve muayene sürelerine ilişkin memnuniyet düzeyinin, 26-35 yaş aralığındaki bireylere göre anlamlı derecede daha fazla olduğu görülmüştür.

Sonuç olarak İstanbul'da hastaların büyük çoğunluğunda sağlıkta dönüşüm programı sonrası sağlık hizmetinden faydalanmanın kolaylaşmadığı düşüncesinin, merkezi hasta randevu sisteminden kolaylıkla randevu alınmasında, randevu saatinde muayene olunmasında, hastalığı takip eden doktora ulaşılmasındaki sorunlara dayalı olarak oluşmuş olduğu görülmüştür. Aile hekimliği uygulaması ilk kademe sağlık birimi olarak faydalı olmakla beraber, katılımcılar genel olarak aile hekimliği uygulamasını devlet hastanelerindeki yoğunluğu azaltmadığı, aile hekimliğinden sevk alınma zorunluluğu getirilse de azaltmayacağı düşüncesine sahiptirler. Performansa dayalı ücret sisteminin ve doktorların hastane dışında muayenehane açmamalarının hastanın yararına olmadığı düşüncesi hakim olup, özel hastanelerde gereksiz tetkik ve işlem yapıldığı düşüncesinin hastaların devlet hastanelerine yönlenmesine sebep olduğu tespit edilmiştir. Araştırma bulguları ve yapılan analizler, İstanbul'da sağlıkta dönüşüm programına dayalı uygulamalara, memnuniyetsizlik kaynağı olduğu tespit edilen hususların iyileştirilmesi suretiyle devam edilmesinin yerinde olacağını göstermektedir. 


\section{Kaynakça}

5502 Nolu Sosyal Güvenlik Kurumu Kanunu (20.05.2006 tarih, 26173 sayılı T.C. Resmi Gazete).

5510 Nolu Sosyal Sigortalar ve Genel Sağlık Sigortası Kanunu (16.06.2006 tarih, 26200 sayılı T.C. Resmi Gazete).

5947 Nolu Üniversite ve Sağlık Personelinin Tam Gün Çalışmasına Dair Kanun (30.01.2010 tarih, 27478 sayılı T.C. Resmi Gazete).

Aile Hekimliği Uygulama Yönetmeliği (25.01.2013 tarih, 28539 sayılı T.C. Resmi Gazete).

AKDAĞ, R. (2008). İlerleme Raporu Türkiye Sağlıkta Dönüşüm Programı. T.C. Sağlık Bakanlığı, Yayın No: 349.

AKDAĞ, R. (2012). Sağlıkta Dönüşüm Programı Değerlendirme Raporu (2003-2011). T. C. Sağlık Bakanlığı, https://dosyasb.saglik.gov.tr/Eklenti/5131,sdpturkpdf.pdf?0 (Erişim Tarihi: 25.10.2018)

AKGÜL YILMAZ, G. (2006). OECD ülkeleri ve Türkiyede Sosyal Devlet ve Sosyal Harcamalar, İstanbul, Arıkan Basım.

AYYILDIZ ONARAN, Z. (2014). Sağlığın Mikrosu, İstanbul, Derin Yayınları.

BULUTOĞLU, K. (2003). Kamu Ekonomisine Giriș: Demokraside Devletin Ekonomik Bir Kuramı, İstanbul, Yapı Kredi Yayınları.

ÇELIKAY, F., GÜMÜŞ, E. (2011).Sağlıkta Dönüşümün Ampirik Analizi, Ankara Üniversitesi SBF Dergisi, 66(3): 55-92.

EMHAN, A., BEZ, Y. (2010). Bir Üniversite Hastanesine Başvuran Hastaların Memnuniyet Düzeyleri, Dicle Tip Dergisi, 37(3): 241-247.

KOÇAK, O., TIRYAKI, D. (2011). Sosyal Devlet Anlayışında Sağlık Politikalarının Önemi ve Sağlıkta Dönüşüm Programının Değerlendirilmesi: Yalova Örneği, İstanbul Ticaret Üniversitesi Sosyal Bilimler Dergisi, 10(19): 55-88.

OECD (2008). OECD Sağllk Sistemi İncelemeleri Türkiye, https://sbu.saglik.gov.tr/ekutuphane/kitaplar/ oecdkitap.pdf (Erişim Tarihi: 20.10.2018).

Sağlık Uygulama Tebliği (24.03.2013 tarih, 28597 sayılı T.C. Resmi Gazete).

SAMUELSON, P. A. (1954). The Pure Theory of Public Expenditures. The Review of Economics and Statistics, 36(4): 387.

SARP, N., TÜKEL, B. (1999). İbn-i Sina Hastanesinde Hasta Memnuniyeti Araştırması, Ankara Üniversitesi Tip Fakültesi Mecmuası, 52: 147-151.

ŞENER, O. (2006). Kamu Ekonomisi, İstanbul, Beta.

SOYSAL, A., YAĞAR, F. (2015).Sağlıkta Dönüşüm Programı: Kahramanmaraş Sütçü İmam Üniversitesi Araştırma ve Uygulama Hastanesinde Bir Araştırma, KSÜ Sosyal Bilimler Dergisi, 12(2): 313-344.

STIGLITZ, J. E. (2000). Economics of the Public Sector, NewYork/London, W. W. Norton \& Company.

T.C. Sağlık Bakanlığı (2003). Sağlıkta Dönüşüm, https://www.saglik.gov.tr/TR,11415/saglikta-donusumprogrami.html (Erişim Tarihi: 20.10.2018).

Türkiye İstatistik Kurumu (TÜIK). Adrese Dayalı Nüfus Kayıt Sistemi, Yıllara Göre İl Nüfusları, 2017, http://www.tuik.gov.tr/PreTablo.do?alt_id=1059 (Erişim Tarihi: 20.04.2018).

Türkiye İstatistik Kurumu (TÜIK). Yaşam Memnuniyeti Araştırması, 2017, http://www.tuik.gov.tr/ PreHaberBultenleri.do?id=27590 (Erişim Tarihi: 25.10.2018).

World Health Organization. (1946). Constitution of the World Health Organization. http://apps.who.int/gb/ bd/PDF/bd47/EN/constitution-en.pdf?ua=1 (Erişim Tarihi: 25.10.2018). 


\section{EK - ANKET FORMU}

\begin{tabular}{|c|c|c|c|c|c|c|}
\hline \multicolumn{2}{|r|}{$\begin{array}{l}\text { Sağlıkta Dönüșüm Programı Sonrası } \\
\text { HASTA MEMNUNIYYTİNE YÖNELİK SORULAR }\end{array}$} & \multirow[t]{2}{*}{ 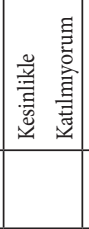 } & \multirow[t]{2}{*}{ 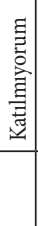 } & \multirow[t]{2}{*}{ 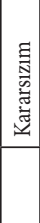 } & \multirow[t]{2}{*}{ 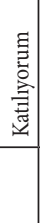 } & \multirow[t]{2}{*}{ 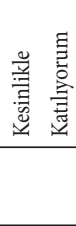 } \\
\hline 1 & $\begin{array}{l}\text { Sağlıkta dönüşüm programı uygulanmaya başladığından beri devlet hastanelerinde muayene } \\
\text { olmam kolaylaştı. }\end{array}$ & & & & & \\
\hline 2 & Sağlıkta dönüşüm programı sonrasında devlet hastanelerinin hizmet kalitesi artmıştır. & & & & & \\
\hline 3 & Sağlikta dönüşüm programı sonrasında devlet hastanelerindeki yoğunluk azalmıștır. & & & & & \\
\hline 4 & $\begin{array}{l}\text { Sosyal güvenlik kurumlarının (SSK, Bağ-Kur, Emekli Sandığı) birleştirilmesiyle herkesin sağlık } \\
\text { hizmetlerinden eşit faydalanması sağlanmıştır. }\end{array}$ & & & & & \\
\hline 5 & $\begin{array}{l}\text { Katılım Payı uygulaması (Muayene sebebiyle eczanede kesilen para) gereksiz yere devlet } \\
\text { hastanelerine gidilmesini engellemektedir. }\end{array}$ & & & & & \\
\hline 6 & $\begin{array}{l}\text { Devlet hastanelerindeki yoğunluk sebebiyle ek ücret ödeyerek özel hastaneye gitmeyi tercih } \\
\text { ederim. }\end{array}$ & & & & & \\
\hline 7 & Aldığım randevu saatinde beklemeden muayene oluyorum. & & & & & \\
\hline 8 & Devlet hastanesinde tedavimi takip eden hekime her zaman ulaşabiliyorum. & & & & & \\
\hline 9 & $\begin{array}{l}\text { Merkezi Hekim Randevu Sistemi (MHRS) ile devlet hastanelerinde istediğim tarihe rahatlıkla } \\
\text { randevu alabiliyorum. }\end{array}$ & & & & & \\
\hline 10 & $\begin{array}{l}\text { Sağlıkta dönüşüm programı uygulanmaya başladığından beri sağlık hizmetlerinden hızlı ve etkin } \\
\text { bir şekilde faydalanabilmekteyim. }\end{array}$ & & & & & \\
\hline 11 & $\begin{array}{l}\text { Eczanelerde alınan muayene katılım payı ve ilaç katılım payı ücretlendirmesini şeffaf ve güvenilir } \\
\text { buluyorum. }\end{array}$ & & & & & \\
\hline 12 & Aile hekimliği uygulaması başladığından beri devlet hastaneleri eskisi kadar yoğun değil. & & & & & \\
\hline 13 & Devlet hastanelerindeki hasta muayenesine yeterli süre ayrılmaktadır. & & & & & \\
\hline 14 & $\begin{array}{l}\text { Katılım payı uygulaması devlet hastanelerindeki sağlık hizmetinden faydalanmamı } \\
\text { engellemektedir. }\end{array}$ & & & & & \\
\hline 15 & $\begin{array}{l}\text { Aile hekiminden sevk alma zorunluluğu getirilirse, devlet hastanelerindeki yoğunluk azalır } \\
\text { böylece devlet hastanesinden daha etkin bir sağlık hizmeti alırım. }\end{array}$ & & & & & \\
\hline 16 & $\begin{array}{l}\text { Aile hekiminden sevk alma zorunluluğu getirilirse, sevk almadan doğrudan devlet hastanesine } \\
\text { gittiğim zaman daha yüksek katılım payı ödesem de devlet hastanesine gitmeyi tercih ederim. }\end{array}$ & & & & & \\
\hline 17 & $\begin{array}{l}\text { Devlet hastanelerinde hekimlerin baktığı hasta sayısına göre (performansa göre) ücret almaları } \\
\text { hastaların yararınadır. }\end{array}$ & & & & & \\
\hline 18 & $\begin{array}{l}\text { Hekimlerin hem devlet hastanelerinde çalışıp hem özel muayenehane açmalarının engellenmesi, } \\
\text { muayenehanelerinin kapatılmasıyla sağlık hizmetinin iyileştiğini düşünüyorum }\end{array}$ & & & & & \\
\hline 19 & Katılım payı ödemediğim için acil servisi tercih ederim. & & & & & \\
\hline 20 & $\begin{array}{l}\text { Aile hekiminden sevk alma zorunluluğu getirilirse, hastalığımın teşhis ve tedavisinde yetersiz } \\
\text { kalma endișesi yaratmaktadır. }\end{array}$ & & & & & \\
\hline 21 & $\begin{array}{l}\text { Özel hastanelerde gereksiz tetkik ve işlemler yapıldığını düşündüğümden özel hastaneleri tercih } \\
\text { etmiyorum. }\end{array}$ & & & & & \\
\hline 22 & $\begin{array}{l}\text { Özel hastaneler arasında farklı tutarlarda ek ücret alınması sağlık hizmetine erişimi olumsuz yönde } \\
\text { etkilemektedir. }\end{array}$ & & & & & \\
\hline 23 & $\begin{array}{l}\text { Devlet hastanelerindeki yoğunluğa ve muayene süresinin kısalığına rağmen özel hastanelerde ek } \\
\text { ücretlerin yüksek olması sebebiyle özel hastaneleri tercih etmem. }\end{array}$ & & & & & \\
\hline 24 & $\begin{array}{l}\text { Sağlıkta dönüşüm programı uygulanmaya başladığından beri devlet hastanelerindeki hekimlerin } \\
\text { hastalarla daha fazla ilgilendiğini düşünüyorum. }\end{array}$ & & & & & \\
\hline 25 & Sağlıkta dönüșüm programı genel olarak sağlık hizmetinden faydalanmamı olumlu etkilemiștir. & & & & & \\
\hline
\end{tabular}




\section{DEMOGRAFIK BILGILER}

1. Yaşınız?.....

2. Cinsiyetiniz? ( ) Kadın ( ) Erkek

3. Medeni Durumunuz? ( ) Evli ( ) Bekar ( ) Boşanmış ( ) Dul

4. Mesleğiniz?

( ) Öğrenci ( ) Ev Kadını ( ) Emekli ( ) Memur ( ) İşçi ( ) İşveren

( ) Serbest Meslek Erbabı ( ) İşsizim ( ) Çalışmıyorum

5. Ortalama aylık geliriniz (hane halkı toplam gelir)?

( ) $1.600 \mathrm{TL}$ ve altında ( ) $1.600-3.500 \mathrm{TL}$ ( ) $3.501-5.000 \mathrm{TL}$ aras1

( ) $5.001-7.000 \mathrm{TL}$ arası ( ) $7.001-10.000 \mathrm{TL}$ arası ( ) $10.000 \mathrm{TL}$ üstü

6. Tamamlamış olduğunuz eğitim seviyesi?

( ) Okuryazar değil ( ) İlkokulu bitirmemiş ( ) İlkokul ( ) Ortaokul

( ) Lise ( ) Yüksekokul ( ) Lisans ( ) Yüksek Lisans ( ) Doktora

7. Eski sistemde tabi olduğunuz sigorta kurumu hangisidir?

( ) Yok ( ) SSK ( ) Bağ-Kur ( ) Emekli Sandığı ( ) Özel Sigorta ( ) Yeşil Kart

8. Bakmakla yükümlü olduğunuz kişi sayısı kaçtır?

( ) Yok ( )1-2 ( )3-4 ( ) 4'den fazla

9. Herhangi bir sağlık sorununuz olduğunda ilk gitmeyi düşündüğünüz sağlık kurumu hangisidir?

( ) Aile Hekimi - Sağlık Ocağı ( ) Devlet Hastanesi ( ) Üniversite Hastanesi ( ) Özel Hastane ( ) Özel Muayenehane

10. Son bir yıl içinde kendiniz yada bir yakınınız sebebiyle sağlık kurumlarına gitme sıklığınız nedir?

( ) Hiç gitmedim ( ) en fazla 5 kere ( ) 6-10 kez ( ) 10'dan fazla 


\section{Extended Abstract}

With the Health Transformation Programme, a series of new applications in the area of finance and provision of the health care services, were brought into the life in Turkey at the year of 2003 in order to reach the aim of more efficient health services. With the reforms that mentioned above, the cost efficiency was tried to be ensured as well as making easy the access to the health services. In that context, a series of measure applied. The most important milestones of the reform at the service supply are as follows; the transition of the health services to the citizen focused supply by the community health centers at the rural areas, and by the primary health services at the urban areas. The transition to the appointment system at hospitals and the extend of opportunities on the utilization from the private hospitals. The main pillars of the reform at the finance of the services are as follows; convergence of the health insurance system, applying the performance measurement system since 2006 and the regulative measures for the pharmaceutical industry. With the measurable performance applications, the service production for the most possible quantity of people with the same quantity of factors (health sector employees); at the same time, reflections of that on the prices were aimed. With the regulative applications at the pharmaceutical sector, lowering the cost of health services was aimed, with the transition to the general health insurance system, more efficient source management that is directed produce health service production was tried to be ensured. The applications that mentioned above have been influential on the patients who demand the health services. We have conducted a field survey in Istanbul with the aim of measuring the satisfaction level of individuals from the healthcare services in order to evaluate the impact of these applications over the patients who demanded health care services in a particular time.

In this study, the data was collected with the simple random sampling method by the face to face and internet based meetings with the 720 individuals, 556 of them was appropriate and used in the analysis. We have applied the independent samples t-test and one-way ANOVA analysis. The data was analyzed with the SPSS 22 software.

It is detected that the Health Transformation Programme is not a facilitative factor for the utilization from the health services because the $30 \%$ of the participants stated that the programme made the health services more accessible but $42,7 \%$ of them are stated their thoughts against. 31,5 $\%$ of the participants says the medical treatments are easier in the Public hospitals and $46,4 \%$ of the participants are not agree with this statement. We can count the reasons of this dissatisfaction as the failures in the central appointment system, problems on reaching the doctor who conducts the treatment and the performance based wage system. As another highlight our study found that the demand for the private hospitals is decreasing because of the thought of that, the private hospitals ask for unnecessary medical examinations. $48,4 \%$ of the participants have this thought and $32,4 \%$ of them are not agree with this thought.

We have examined whether there is a statistical significant difference between the factors which composing the satisfaction of the health care services by considering several independent variables. For the variables like gender, marital status, education level and frequency of visiting 
health care institutions, we have applied the independent samples t-test and for other variables like age, number of dependents and income level, we have applied one-way ANOVA analysis.

After the analysis, whether there is a significant difference between selected groups in terms of general satisfaction from health care services, we see that there is a significant difference between men and women. The men are significantly more satisfied from the health care services than women are. When we analyze the patients in terms of education levels, the individuals who have degrees less than undergraduate are more satisfied from health care services than the individuals who have degrees equal to undergraduate or higher. The individuals who have visited a health care institution less than five times in the last year are more satisfied with the health care services than the ones who have visited more than five. The individuals who have more than three dependants are more satisfied with the health care services than the individuals who have one or two dependants when we evaluate the results in terms of the number of dependants. In terms of the ages of patients, we found that the individuals between the ages of 18-25 are more satisfied from the health care services than the individuals between the ages of 26-35. We have found that there is no significant difference among the individuals in terms of marital status and in terms of income level.

According to the evaluations, whether there is a significant difference between the groups in terms of satisfaction level with the participation fee, we have founded that the individuals who have degrees less than undergraduate level are more satisfied with the participation fee application than the individuals who have an undergraduate degree. The individuals who have visited a health care institution at most five times in the last year are more satisfied with the participation fee than the ones who have visited more than five. In terms of the ages of patients, we found that the individuals between the ages of 18-25 are more satisfied from the participation fee than the individuals between the ages of 26-35 are. We have found that there is no significant difference among the individuals in terms of gender, marital status, dependent number and income level.

As a last highlight, we analyzed that whether there is a statistical significant difference between the selected groups in terms of satisfaction with the appointment system and the durations of medical examinations. As a result of these analyses, we have found that the men are significantly more satisfied with the appointment system and the durations of medical examination than the women are. We have founded that the individuals who have degrees less than undergraduate level are more satisfied with the appointment system and the durations of medical examinations than the individuals who have an undergraduate degree. When we evaluate according to the frequency of visiting health care institutions, the individuals who have visited the health care institutions at most five times are more satisfied with the appointment system and the duration of medical examination than the individuals who have visited health care institutions more than five times. The individuals who have more than three dependants are more satisfied than the individuals who have one or two dependants. In terms of the ages of patients, we found that the individuals between the ages of 1825 are more satisfied with the appointment system and the durations of medical examinations than the individuals between the ages of 26-35 are. We have found that there is no significant difference among the individuals in terms of marital status and in terms of income level. 